\title{
Pola Penyakit Malaria pada Anak Di RSU Manna, Bengkulu Selatan
}

\author{
Hindra Irawan Satari
}

Penyakit malaria sampai saat ini masih merupakan masalah kesehatan yang perlu diperhatikan di negara kita, karena penyakit ini masih termasuk dalam kelompok lima besar pola penyakit anak di Puskesmas, demikian pula di Rumah Sakit Umum Manna Bengkulu Selatan. Untuk mengetahui pola penyakit malaria pada anak yang di rawat RSU Manna, dilakukan penelitian retrospektif dari dokumen medik pasien yang dirawat dari tanggal 1 Januari 1990 sampai dengan 31 Desember 1992. Dalam kurun waktu tersebut telah dirawat 122 anak pasien malaria, tetapi dari jumlah tersebut hanya 68 pasien $(55,7 \%)$ yang memenuhi syarat penelitian yang terdiri atas 41 pasien anak laki-laki $(60,3 \%)$ dan 27 pasien anak perempuan (39,7\%). Semua pasien diobati sesuai dengan pedoman pengobatan yang dikeluarkan oleh Departemen Kesehatan R.I. Empat pasien di antaranya meninggal dunia (5,9\%). Kelompok umur yang terbanyak adalah kelompok umur 1-4 tahun (38,2\%), sedangkan parasit penyebab terbanyak adalah Plasmodium vivax (58,8\%). Manifestasi klinis adalah demam (100\%), diikuti oleh muntah (39,7\%), sedangkan menggigil bukan merupakan gejala yang terbanyak (32,3\%). Hepatomegali dan mencret ditemukan pada 33,9\% pasien, sedangkan splenomegali didapatkan pada $8,7 \%$ pasien. Pada penelitian ini tampak pedoman pengobatan dari Departemen Kesehatan R.I. masih menunjukkan hasil yang baik.

Kata kunci: malaria, Plasmodium vivax.

(1) enyakit malaria telah diketahui sejak zaman Hippocrates. Gejala penyakit ini ditandai dengan demam tinggi, yang biasanya intermiten, anemia dan splenomegali. Namun pada anak di bawah usia 5 tahun gejala karakteristik tersebut tidak tampak jelas, bahkan makin muda usia gejala makin tidak jelas, dan umumnya gejala yang menonjol adalah diare dan anemia ${ }^{1,2}$.

Pada manusia terdapat 4 spesies plasmodium, yaitu Plasmodium vivax, Plasmodium-falciparum, Plasmodium malariae dan Plasmodium ovale. Plasmodium falciparum dapat memperlihatkan manifestasi klinis akut yang apabila tidak segera diatasi dapat mengakibatkan

\footnotetext{
Alamat Korespondensi:

Dr. Hindra Irawan Satari Sp.A(K),MTropPaed.

Subbagian Infeksi Penyakit Tropis, Bagian Ilmu Kesehatan Anak FKUI-RSCM Jl. Salemba no. 6, Jakarta 10430.

Telepon: 021-3914126. Fax.021-390 7743
}

kematian dalam waktu beberapa hari setelah awitan, sehingga disebut juga sebagai malignant tertian malaria, sedangkan plasmodium. lainnya jarang berakibat fatal.

Sampai saat ini tidak kurang dari 1 juta orang yang meninggal disebabkan oleh malaria di negara-negara tropis, sebagian besar di antaranya menimpa anak-anak di bawah usia 5 tahun $^{3}$. Di Indonesia penyakit malaria ditemukan tersebar di seluruh kepulauan, sedangkan di luar Jawa Bali fokus malaria terutama di Indonesia bagian Timur. Insidens penyakit malaria di Jawa Bali diukur dengan menggunakan Annual Parasite Incidence (API). Di luar Jawa Bali, prevalensi di daerah prioritas (daerah transmigrasi, daerah perbatasan, daerah pembangunan sosial ekonomi) diukur dengan menggunakan Parasite Rate (PR), sedangkan insiden di luar daerah prioritas diukur dengan Slide Positive Rate (SPR). API penyakit malaria di Jawa dan Bali menurun tajam dari 1,34/1000 penduduk pada tahun 1983, menjadi 0,16/1000 penduduk pada tahun 1990. 
Dari kegiatan survai malariometrik di luar wilayah Jawa Bali tampak bahwa PR meningkat dari 4,50/1000 penduduk tahun 1984 , menjadi 4,84 \% pada tahun 1990 dengan prevalensi tertinggi di Propinsi Irian Jaya, Sulawesi Utara, Maluku, Timor Timur dan Sulawesi Tengah ${ }^{4}$. Angka SPR pengunjung Puskesmas dari luar daerah prioritas di luar Jawa Bali menurun dari 40,8 $\%$ menjadi 30,6 \% yang berarti pada tahun 1988 tersebut terdapat 116.010 orang pasien. Parasite rate untuk semua golongan umur di Bengkulu berkisar di antara 2-5\%5. Kabupaten Bengkulu Selatan masih merupakan daerah endemis malaria dan sampai tahun 1992 malaria klinis masih berada pada posisi ketiga dalam urutan sepuluh besar pola kesakitan ${ }^{6}$.

Tujuan penelitian ini adalah untuk mengetahui angka insidens malaria pada anak, proporsi pasien yang dirawat, jenis kelamin, sebaran umur, parasit penyebab, manifestasi klinis, hasil pengobatan termasuk angka kematian dan penyebab kematian pada pasien yang dirawat di RSU Manna, Bengkulu Selatan.

\section{Bahan dan Cara}

Data diambil dari Bagian Rekam Medik RSU Manna dan Laporan Tahunan Dinas Kesehatan Kabupaten DATI II Bengkulu Selatan. Data adalah pasien yang dirawat dalam kurun waktu 1 Januari 1990 sampai dengan 31 Desember 1992. Pasien dikelompokkan menjadi 4 golongan umur, sesuai dengan petunjuk buku laporan bulanan yang dikeluarkan oleh Departemen Kesehatan R.I., yaitu masing-masing: kelompok umur $<1$ tahun, golongan umur 1-4 tahun, dan kelompok 5-14 tahun. Dikumpulkan data dari dokumen medik yang berisi anamnesis, pemeriksaan fisis dan pemeriksaan laboratorium yang mencakup antara lain pemeriksaan darah tepi dan sediaan apus darah tebal.

\section{Batasan operasional}

1. Diagnosis Malaria falciparum ditegakkan apabila dalam darah tepi ditemukan Plasmodium falsiparum.

2. Diagnosis Malaria vivax ditegakkan apabila dalam darah tepi ditemukan Plasmodium vivax.

3. Diagnosis malaria klinis ditegakkan apabila dalam darah tepi pasien tidak ditemukan plasmodium, tetapi secara klinis menunjukkan malaria dan menunjukkan respons dengan pengobatan malaria.

4. Pengobatan malaria dilakukan dengan pemberian klorokuin atau sulfadoksin pirimetamin sesuai dengan petunjuk pengobatan malaria dari Departemen Kesehatan R.I.

Data hasil penelitian diolah dan disajikan secara info deskriptif, menggunakan program statistik Epi Info 5.01B.

\section{Hasil}

Data yang berhasil dikumpulkan untuk semua golongan umur pasien malaria klinis menunjukkan adanya penurunan sejak tahun 1990 sampai dengan tahun 1992, yaitu berturut-turut 7787 (1990), 6630 (1991) dan 5969 kasus (1992), atau dengan perkataan lain terlihat penurunan angka insidens dari 2,6 kasus/ 1000 penduduk pada tahun 1990 menjadi 1,9 kasus/ 1000 penduduk pada tahun 1992 (Tabel 1).

Tabel 1. Pasien malaria klinis semua golongan umur di Kabupaten Bengkulu Selatan tahun 1990-1992

\begin{tabular}{lccc}
\hline Tahun & $\begin{array}{c}\text { Jumlah } \\
\text { penduduk }\end{array}$ & $\begin{array}{c}\text { Jumlah } \\
\text { kasus baru }\end{array}$ & $\begin{array}{c}\text { Angka insiden/ } \\
1000 \text { penduduk }\end{array}$ \\
\hline 1990 & 299966 & 7787 & 2.6 \\
1991 & 301497 & 6630 & 2.2 \\
1992 & 312040 & 5969 & 1.9 \\
\hline
\end{tabular}

Sumber: Laporan tahunan Dinas Kesehatan Kabupaten Dati II Bengkulu Selatan tahun 1990 - 1992.

Keadaan pada Tabel 1 berbeda dengan data dari RSU Manna yang menunjukkan adanya peningkatan proporsi jumlah pasien rawat malaria pada tahun 1991 dan tahun 1992 (Tabel 2). Bila seluruh pasien selama 3 tahun digabungkan maka proporsi pasien malaria

Tabel 2. Proporsi pasien malaria pada anak yang dirawat di RSU Manna tahun 1990 s/d 1992

\begin{tabular}{lccc}
\hline Tahun & $\begin{array}{c}\text { Jumlah } \\
\text { seluruh pasien }\end{array}$ & $\begin{array}{c}\text { Pasien } \\
\text { malaria }\end{array}$ & $\begin{array}{c}\text { Proporsi } \\
\text { (Persen) }\end{array}$ \\
\hline 1990 & 341 & 28 & 8,2 \\
1991 & 388 & 49 & 12,6 \\
1992 & 343 & 45 & 13,1 \\
\hline Jumlah & 1072 & 122 & 11,3 \\
\hline
\end{tabular}

Sumber: Bagian Rekam Medik Rumah Sakit Umum Manna. 
yang dirawat di bangsal anak ialah 11,3\%.

Dari seluruh pasien yang dirawat di RSU Manna dalarn kurun waktu penelitian, hanya didapatkan 68 $(55,7 \%)$ catatan medik yang memenuhi syarat untuk diteliti.

Tabel 3 memperlihatkan distribusi jenis kelamin pasien malaria pada anak di RSU Manna. Terlihat jumlah pasien anak laki-laki lebih banyak daripada anak perempuan.

Tabel 3. Distribusi jenis kelamin pasien malaria pada anak yang dirawat di RSU Manna 1990-1992

\begin{tabular}{lccccc}
\hline Tahun & Laki-laki & $\%$ & Perempuan & $\%$ & Jumlah \\
\hline 1990 & 15 & 68,2 & 7 & 31,8 & 22 \\
1991 & 22 & 68,7 & 10 & 31,3 & 32 \\
1992 & 6 & 42,9 & 8 & 57,1 & 14 \\
\hline Jumlah & 41 & 60,3 & 27 & 39,7 & 68 \\
\hline
\end{tabular}

Tampak pada Tabel 4 kelompok umur 1-4 tahun merupakan kelompok umur terbanyak $(38,2 \%)$. Meskipun demikian perbedaan tidak begitu besar apabila dibandingkan dengan jumlah pasien kelompok umur 5 - 14 tahun (36,8\%), namun cukup jelas

Tabel 4. Distribusi pasien malaria pada anak menurut golongan umur yang dirawat di RSU Manna tahun $1990-1992$

Kelompok umur (tahun)

\begin{tabular}{lccccccc} 
Tahun & $<1$ & $\%$ & $1-4$ & $\%$ & $5-14$ & $\%$ & Jumlah \\
\hline 1990 & 8 & 36,4 & 8 & 36,4 & 6 & 28,2 & 22 \\
1991 & 8 & 25,0 & 13 & 40,6 & 11 & 34,4 & 32 \\
1992 & 1 & 7,2 & 5 & 35,7 & 8 & 57,1 & 14 \\
\hline Jumlah & 17 & 25,0 & 26 & 38,2 & 25 & 36,8 & 68
\end{tabular}

berbeda dengan kelompok umur $<1$ tahun (25\%). Umur termuda pada penelitian ini adalah bayi berumur 8 minggu.

Pada Tabel 5 tampak bahwa Plasmodium vivax merupakan parasit terbanyak $(58,8 \%)$ sebagai penyebab malaria.

Tabel 5. Jenis penyebab malaria pada anak menurut parasit penyebab yang dirawat di RSU Manna tahun 1990 1992

\begin{tabular}{lccccc}
\hline Jenis & 1990 & 1991 & 1992 & Jumlah & $\%$ \\
\hline P. falciparum & 3 & 9 & 7 & 19 & 27,9 \\
P. vivax & 17 & 17 & 6 & 40 & 58,8 \\
Malaria klinis & 2 & 6 & 1 & 9 & 13,3 \\
\hline Jumlah & 22 & 32 & 14 & 68 & 100 \\
\hline
\end{tabular}

Dari Tabel 6 terlihat semua pasien mengeluh demam (100\%). Menggigil bukan merupakan keluhan yang terbanyak $(32,3 \%)$, bahkan muntah merupakan keluhan yang terbanyak sesudah demam $(39,7 \%)$. Demam, muntah dan mencret pada penelitian ini merupakan keluhan yang terbanyak yang ditemui. Hepatomegali merupakan gejala terbanyak $(33,9 \%)$. Splenomegali hanya didapatkan pada $8,9 \%$ pasien, sedangkan anemia $26,5 \%$. Pasien mendapat pengobatan sesuai dengan petunjuk dari Departemen Kesehatan Republik Indonesia dan hasil pengobatannya dapat dilihat dari Tabel 7.

Sebagian besar pasien pulang dalam keadaan sembuh (76,5\%), pulang atas permintaan sendiri 17,6\%, sedangkan pasien yang meninggal 4 (5,9\%) orang.

Karakteristik pasien, parasit penyebab dan penyebab kematian dapat dilihat pada tabel 8 di bawah ini.

Sebagian besar kematian pada pasien anak di RSU

Tabel 6. Manifestasi klinis malaria pada anak yang dirawat di RSU Manna tahun 1990 - 1992

\begin{tabular}{lcclcc}
\hline Gejala Klinis & Jumlah & $\%$ & Pemeriksaan Klinis & Jumlah & $\%$ \\
\hline Demam & 68 & 100 & Hepatomegali & 23 & 33,9 \\
Muntah & 27 & 39,7 & Anemia & 18 & 26,5 \\
Diare & 23 & 33,9 & Splenomegali & 6 & 8,9 \\
Menggigil & 22 & 32,3 & Ikterus & 2 & 2,9 \\
Kejang & 14 & 20,6 & Kesadaran menurun & 2 & 2,9 \\
Batuk & 10 & 14,7 & Perdarahan & 1 & 1,5 \\
Nyeri kepala & 9 & 13,2 & & & \\
\hline
\end{tabular}


Sari Pediatri, Vol. 4, No. 3, Desember 2002

Tabel 7. Hasil pengobatan malaria pada anak yang dirawat di RSU Manna tahun 1990 - 1992

\begin{tabular}{lccrrr}
\hline Hasil Pengobatan & \multicolumn{3}{c}{ Tahun } & \multirow{2}{*}{ Jumlah } \\
\cline { 2 - 4 } & 1990 & 1991 & 1992 & \\
\hline Sembuh (\%) & $18(81,9)$ & $23(71,9)$ & $11(78,6)$ & $52(76,5)$ \\
Pulang atas permintaan (\%) & $4(19,1)$ & $6(18,8)$ & $2(14,3)$ & $12(17,6)$ \\
Meninggal (\%) & 0 & $2(2,9)$ & $2(2,9)$ & 4 & $(5,8)$ \\
\hline Jumlah & 22 & 31 & 14 & 68 \\
\hline
\end{tabular}

Manna disebabkan oleh Plasmodium falciparum (Tabel 8). Bronkopneumonia tampak memperberat keadaan pasien malaria, bahkan mungkin merupakan penyebab utama kematian utama pada pasien-pasien tersebut. Penyebab kematian pada anak yang kedua tidak dapat ditemukan, kecuali malaria tropika. Terdapat 2 kasus meninggal dengan penyebab utama kematian tersangka malaria serebral, tetapi pada pasien yang lebih muda hasil yang berbeda-beda oleh para peneliti. Jain $\mathrm{dkk}^{7}$, melaporkan dari 208 pasien malaria serebral dewasa ternyata lebih banyak pasien laki-laki yang dirawat bila dibandingkan dengan pasien perempuan (rasio 7:3), sedangkan Hadisaputro dkk. ${ }^{8}$ mendapatkan rasio laki-laki dengan perempuan pada pasien malaria berat dewasa adalah 1:1. Penelitian ini mendapatkan perbandingan laki laki dengan perempuan sebanyak $6: 4$, hal ini juga belum

Tabel 8. Karakteristik pasien malaria pada anak, parasit penyebab dan penyebab kematian yang dirawat di RSU Manna tahun 1990 s/d 1992

\begin{tabular}{lrlll}
\hline Tahun & Umur & Kelamin & Parasit penyebab & Penyebab kematian \\
\hline 1990 & & tidak ada kematian & & \\
1991 & $10 \mathrm{thn}$ & laki-laki & P. vivax & Bronkopneumonia \\
& $4 \mathrm{bln}$ & laki-laki & P. falciparum & Malaria tropika \\
1992 & $7 \mathrm{bln}$ & perempuan & P. falciparum & Bronkopneumonia \\
& $9 \mathrm{thn}$ & laki-laki & Malaria klinis & Malaria serebral \\
& & & Malaria serebral \\
\hline
\end{tabular}

terdapat pula penyakit penyerta bronkopneumonia yang memperberat keadaan penyakitnya seperti telah diuraikan di atas.

\section{Pembahasan}

Melihat penurunan secara bertahap angka insidens penyakit malaria untuk semua golongan umur, tampak program pemberantasan malaria di Bengkulu Selatan cukup berhasil, meskipun demikian keadaan ini masih tetap lebih tinggi apabila dibandingkan dengan angka insidens di Jawa Bali pada akhir Pelita IV yaitu sebesar 0,3 per 1000 penduduk ${ }^{5}$ Di lain pihak proporsi pasien anak di RSU Manna menunjukkan kenaikan, kenyataan ini sulit untuk dijawab, dan perlu diteliti lebih lanjut.

Rasio pasien laki-laki dengan perempuan dilaporkan ada dapat diterangkan penyebabnya.

Frekuensi umur terbanyak terdapat pada kelompok umur 1-4 tahun (38,2\%). Apabila angka ini dijumlahkan dengan kelompok umur 1 tahun maka didapat jumlah pasien anak balita sebanyak 63,2\%. Keadaan ini sama dengan yang dilaporkan oleh Albar dkk. ${ }^{9}$ yang mendapatkan 57,89 \% pasien malaria yang dirawat adalah anak balita. Petunjuk dari Departemen Kesehatan R.I. menyatakan bahwa golongan umur 2-9 tahun merupakan kelompok yang peka terhadap malaria ${ }^{10}$. Penelitian yang dilakukan oleh Cox $\mathrm{dkk}^{11}$ pada pasien anak yang menderita parasitemia asimtomatik memperlihatkan penurunan insiden demam pertahun pada pasien dengan bertambahnya umur. Bethell $\mathrm{dkk},{ }^{12}$ menemukan umur rata-rata pasien malaria berat pada anak 6,8 tahun dengan rentang umur antara 5 bulan sampai 14 tahun. Pasien termuda pada penelitian ini adalah seorang bayi yang berumur 6 minggu. la seorang 
bayi perempuan yang pada sediaan apus darah tebalnya ditemukan parasit Plasmodium vivax, sedangkan demam, anemia dan splenomegali didapatkan sebagai manifestasi klinisnya. Pasien tersebut sembuh dengan pernberian klorokuin. Anak yang dilahirkan oleh ibu yang tinggal di daerah holoendemik telah dibuktikan oleh Gottschau dkk. ${ }^{13}$ mendapat antibodi maternal secara pasif, dengan waktu perlindungan yang diperoleh sampai 4 bulan. Namun ternyata yang terstimulasi hanya respons cell-mediated sedangkan respons humoral tidak terangsang, maka kekebalan yang diperoleh anak tersebut biasanya tidak menyeluruh ${ }^{14}$.

Di Rumah Sakit Umum Manna dalam kurun waktu penelitian selama 3 tahun ini, parasit sebagai penyebab terbanyak adalah Plasmodium vivax $(58,8 \%)$, hal ini sarna seperti yang dilaporkan oleh Soetono dkk. ${ }^{15}$, dan juga ditemukan pada pasien malaria dewasa di Cina. ${ }^{16}$ Di Thailand Plasmodium vivax merupakan $45 \%$ penyebab malaria pada pasien dewasa ${ }^{17}$, di Malaysia 50\% kasus malaria disebabkan oleh Plasmodium falciparum, 40,6\% disebabkan oleh Plasmodium vivax ${ }^{18}$, sedangkan di Papua New Guinea pada anak Plasmodfum falciparum merupakan parasit penyebab terbanyak (39\%), sedangkan Plasmodium vivax sebagai penyebab berkisar $24 \%$. Untuk melihat apakah ada hubungan umur tertentu dengan rentannya pasien tesebut terhadap salah satu parasit penyebab, telah dilakukan uji statistik ternyata tidak bermakna.

Keluhan pasien terbanyak pada penelitian ini adalah demam (100\%) yang diikuti dengan muntah $(39,7 \%)$ dan mencret $(33,9 \%)$ di urutan kedua dan ketiga. Mengenai pemeriksaan fisis penelitian ini mendapatkan hepatomegali sebagai yang terbanyak diikuti oleh anemia di urutan kedua dan splenomegali di urutan ketiga. Keadaan demam dan muntah sebagai keluhan di urutan pertama dan kedua sama seperti dengan apa yang ditemukan oleh Soetono dkk, sedangkan menggigil diletakkan sebagai urutan ketiga. ${ }^{15}$ Bethel ${ }^{12}$ menemukan demam di urutan pertama, muntah di urutan kedua (54\%), tetapi nyeri kepala yang berada pada urutan ketiga dari pasien malaria berat yang dilaporkannya. Adapun mengenai urutan penemuan pemeriksaan fisis terbanyak yang ditemukan pada penelitian ini sama halnya dengan penelitian Soetono dkk. ${ }^{15}$ yang mendapatkan hepatomegali sebagai urutan pertama diikuti oleh anemia dan splenomegali. Namun data itu berbeda dengan yang dinyatakan oleh Bethel dkk. ${ }^{12}$ yang menemukan splenomegali di urutan kedua dan anemia di urutan ketiga. Perbedaan dengan penelitian Bethel mungkin disebabkan oleh karena penelitian yang dilakukan olehnya hanya mengevaluasi pasien Malaria falciparum tropika yang berat saja. Bila seluruh manifestasi klinis tadi diuji secara statistik untuk melihat apakah ada hubungannya dengan umur ternyata hanya mencret yang hasilnya bermakna $(\mathrm{p}=0,0003)$.

Pengobatan radikal dilakukan sesuai dengan buku petunjuk pengobatan yang diterbitkan Departemen Kesehatah Republik Indonesia, ${ }^{19}$ yaitu dengan klorokuin atau sulfadoksin-pirimetamin. Bila pasien pada awal pengobatan tidak dapat minum obat per oral maka diberikan klorokuin intra muskular. Dinas Kesehatan Kabupaten Dati II Bengkulu Selatan Sie P2 Menular telah melakukan uji resistensi Plasmodium falciparum dan ternyata masih sensitif terhadap klorokuin, ${ }^{6}$ hal ini sesuai dengan hasil pengobatan yang memperlihatkan masih banyaknya pasien yang sembuh yaitu sebanyak $76,5 \%$ sedangkan $17,6 \%$ diantaranya pulang atas permintaan sendiri sehingga tidak dapat diketahui hasil akhirnya. Mengenai 4 pasien yang meninggal $(5,9 \%)$, dua pasien meninggal selain oleh karena menderita malaria juga diperberat oleh bronkopneumonia. Seorang pasien lainnya meninggal karena malaria tropika dan sampai saat kematiannya tidak dapat dibuktikan adanya penyebab kematian lain. Pasien ini berumur 4 bulan dengan parasit penyebabnya adalah Plasmodium falciparum, hal ini mungkin disebabkan oleh karena kekebalan yang dipunyainya memang belum sempurna, karena baru respons cellmediated yang terangsang. Angka kematian pada anak di bawah 3 tahun di Afrika adalah 8/1000/tahun. ${ }^{20}$ Penyebab kematian pada malaria biasanya adalah malaria serebral. Winstanley ${ }^{21}$ menemukan $10-40 \%$ pasien malaria serebral pada anak meninggal dunia, selain itu malaria serebral merupakan penyebab penting untuk terjadinya defisit neurologik pada anak-anak. ${ }^{22}$ Pada penelitian ini kedua pasien terakhir meninggal oleh karena malaria serebral, seorang bayi berumur 7 bulan disamping menderita malaria serebral, juga menderita bronkopneumonia. Sedangkan seorang anak lainnya yang berumur 9 tahun, meskipun tidak dapat ditemukan parasit malaria pada darah tepinya namun secara klinis jelas menunjukkan gejala malaria serebral.

\section{Kesimpulan}

Angka insiden penyakit malaria di Kabupaten Dati II Bengkulu Selatan menunjukkan penurunan dari tahun 
ke tahun, namun proprosi penyakit malaria rawat inap di Rumah Sakit Umum Manna menunjukkan peningkatan. Pasien anak laki-laki lebih banyak dibandingkan dengan anak perempuan. Anak balita merupakan kelompok umur yang terbanyak. Penelitian ini mendapatkan pula Plasmodium vivax sebagai parasit penyebab terbanyak, disamping itu demam, muntah, mencret dan hepatomegali, anemi baru diikuti splenomegali merupakan manifestasi klinis yang terbanyak. Pengobatan seperti yang dianjurkan oleh Departemen Kesehatan RI sampai saat penelitian ini dibuat tampak masih menunjukkan hasil yang baik. Kematian terbanyak disebabkan oleh Plasmodium falciparum, sedangkan bronkopneumonia memperberat bahkan merupakan penyebab utama kematian.

\section{Daftar Pustaka}

1. Clyde DF. Malaria. Dalam : Behrman RE, penyunting. Nelson Textbook of Pediatrics, 14 th ed .Tokyo: Saunders, 1983. h. 876-9.

2. Ditjen. PPM \& PLP. Malaria: Epidemiologi. Departemen Kesehatan RI, Jakarta 1990; 1:24-8.

3. Lee EL. Common parasitic infections. Dalam : Robinson JM, Lee, EL, penyunting. Paediatric problems in tropical countries, edisi ke-2. Singapore: PG Publishing, 1991. h. 199-204.

4. Pusat Data Kesehatan. Profil Kesehatan Indonesia 1991. Departemen Kesehatan RI, Jakarta 1992.

5. Arbani PR. Rencana pemberantasan malaria di Indonesia menjelang tahun 2000. Dalam Wita P, Rusli M, Inge $S$, penyunting. Kumpulan Makalah Simposium Malaria. Jakarta: Balai Penerbit FKUI, 1991.h. 9-24.

6. DinKes Kab Dati 11 Bengkulu Selatan. Laporan Tahunan Program Pemberantasan Penyakit Menular Tahun Anggaran 1992/1993.

7. Jain AK, Sharma H. Cerebral malaria - A study of 208 cases. Dipresentasikan pada XIIIth International Congress for Tropical Medicine and Malaria, Bangkok 1992.

8. Hadisaputro S, Ardana K, Djamil A. Pola klinik dan pengelolaan malaria berat di RSU RA. Kartini Jepara, Jawa Tengah. Dalam : Wita Pribadi, Rusli Mulyono, Inge Sutanto, penyunting. Kumpulan Makalah Simposium Malaria. Jakarta: Balai Penerbit FKUI 1991. h. 71-84

9. Albar H, Agustina IS, Hangewa P, Syamsiah 1. Dipresentasikan pada. Konika VIII.Ujung Pandang 1990.
10. Direktorat Jenderal Pencegahan dan Pernberantasan. Penyakit Menular Departemen Kesehatan RI. Malaria : survai malariometrik. Jakarta 1983; 6:4-11.

11. Cox MJ, Kum D, Tavul L, Raiko A, Balsor K Alpers M, Medley G, Day KP. Longitudinal study of malaria morbidity in children of Madang, Papua New Guinea. Dipresentasikan pada XIIIth International Congress for Tropical Medicine and Malaria, Bangkok 1992.

12. Bethell D, Waller D, Dung NK, Nehn LTN, Loan HT, Dung NQ, Wffite NJ. A XIIIth prospective study of severe malaria in Vietnamese children. Dipresentasikan pada International Congress for Tropical Medicine and Malaria, Bangkok 1992.

13. Gottschau A, Hogh B. Estimation of incidence of Plasmodium falciparum parasites in infants living in a holoendemic area using methods for interval censored data. Dipresentasikan pada XIIIth International Congress for Tropical Medicine and Malaria, Bangkok 1992.

14. Rasheed FN, Bulmer JN, Francisco S, Jawla W, Jakobsen $\mathrm{PH}$, Jepson, Greenwood BM. Relationship of maternal and neonatal immune responses to malarial antigens. Dipresentasikan pada XIIIth International Congress for Tropical Medicine and Malaria, Bangkok 1992.

15. Soetono, Anggoro DB, Herawati, Tony W, Slamet W. Dipresentasikan pada VIIIth KONIKA, Ujung Pandang 1990.

16. Yang Bai-In. Variability of incubation period and its close association with relapse patterns in vivax malaria. Dipresentasikan pada XIIIth International Congress for Tropical Medicine and Malaria, Bangkok 1992.

17. Rajkulchai P, Wilairat P, Panyim S. DNA probe for specific detection of Plasmodium vivax. Dipresentasikan pada XIIIth International Congress for Tropical Medicine and Malaria, Bangkok 1992.

18. Sidhu PS. A retrospective study on malaria cases admitted to the university Hospital, Kuala Lumpur, 1984-1988. Med J Malaysia 1991; 46:177-82.

19. Ditjen PPM \& PLP. Malaria : Pengobatan. Departemen Kesehatan RI, Jakarta 1986; 3:41-6.

20. Velema JP, Alihonou EM, Chippaux JP, van Boxel Y, Gbedji E, Adegbini R. Malaria morbidity and mortality in children under three years of age on the coast of Benin, West Africa. Trans R Soc Trop Med Hyg 1991, 85:430-5.

21. Winstanley P, Newton C, Watkins W, Ward S, Mwangi 1, Waruiru C, Warell D, Marsh K. Quinine disposition in young children with cerebral malaria. Dipresentasikan pada at XIIIth International Congress for Tropical Medicine and Malaria, Bangkok 1992.

22. Bondi FS. The incidence and outcome of neurological abnormalities in childhood cerebral malaria : a long-term follow-up of 62 survivors. Trans R Soc Trop Med Hyg 1992; 86:17-9. 